ARTICLE

Received 25 Sep 2014 | Accepted 16 Jan 2015 | Published 24 Feb 2015

\title{
The mediatization of politics in contemporary Scandinavian film and television
}

Ib Bondebjerg ${ }^{1}$

ABSTRACT The increased mediatization of society since 1960 has lead to a discussion of the mediatization of politics and the role of media for political debate and democracy. Habermas as early as 1962 discussed the rise and potential decline of the public sphere. The role of media in general was central in this debate, and the rise of the internet in modern societies has increased the analysis and theories of the mediatization of politics in theories of democracy and in media sociology. Audio-visual media and the new digital media have increased the visibility of all parts of private and public life and changed the relation between media, public figures and the citizen. In this article, I will discuss main positions in theories on the mediatization of politics. I will also discuss and analyse three types of film and television genres that reflect this mediatization of politics in Scandinavian film and television culture: the political documentary, the political drama and the "nordic noir" crime genre.

\footnotetext{
${ }^{1}$ Department of Media, Cognition and Communication, University of Copenhagen, Copenhagen, Denmark (e-mail: bonde@hum.ku.dk)
} 


\section{Introduction}

n Fall 2010, Danish Public Service broadcaster DR started the broadcasting of the drama series Borgen, which was not just a huge, national success, but also went on to success in more than 60 countries around the world. Politics is not just a central theme in this series; it is the very stuff the plot and narrative is made of, and in that sense it points to the rise of politics as a mediated phenomenon, as something which is so central to our modern-day society and everyday life that it becomes the main topic of popular television drama. During 30 episodes over three seasons we are not just confronted with politics in the public sphere, but also the backstage of the political game, the struggle for controlling the media agenda and the "vultures" from the media. We experience close up the consequences of politics and of being a politician-all the way into the bedroom of some of the main characters, both politicians and journalists. The main character, Birgitte Nyborg (played by Sidse Babett Knudsen), goes all the way to become prime minister, then losing power and gaining it again, but she also pays a high price in her family life. The series in an almost documentary way takes us through some of the main political issues in Danish politics. The political figures and some of the key media figures represent social and psychological types with a broader reference to modern everyday life in a welfare state like Denmark and in Europe in general.

In some forms of political theory, politics may be seen primarily in relation to aspects having to do with rationality, arguments and debate taking place in the public sphere. But in fact politics is also about drama, emotions, conflicts, and about personality and rhetorical strategies. As Lakoff (2008) has argued in The Political Mind, the Enlightenment concept of politics and the way citizens relate to politics may be rather far away from reality:

According to Enlightenment reason was assumed to be conscious, universal, disembodied, logical, unemotional, value neutral, interest based and literal (...) but voters don't behave like that (...) Language gets its power because it is defined relative to frames, prototypes, metaphors, narratives, images and emotions. Part of its power comes from its unconscious aspects. (Lakoff, 2008: 16)

Politics has certainly played a strong role as a key dramatic element in theater, novels, film and television, and often the moral, emotional dimension has been strong. Frank Capra's Mr. Smith Goes to Washington (1939) is the classical prototype of the idealistic outsider confronting the corrupt political system, and Hollywood has often taken the political road in film. The new transnational online channels like $\mathrm{HBO}$ and Netflix also play a major role here. Most recently with the Netflix series House of Cards (2013-), where we are inside the modern, mediatized political universe, a universe of pure power games, media strategies and scrupulous exploitation of human beings. It is political drama of the highest quality, but it is not very much about reason and logic, except in the name of getting power and getting rid of rivals. The series is in fact not an original product, but an American remake of the BBC series of the same name from 1990, written by Andrew Davies and Michael Dobbs. The rather direct and smooth translation from the United Kingdom to the United States indicates the transnational similarities of the forms of mediatization of politics, although played out with national variations and differences.

A similar tradition for political film and television drama runs through Scandinavia. The tradition grows stronger after 1960 and thus follows the rise of modern mediatized politics. Again this indicates that although the political systems in Denmark, the United Kingdom and the United States are rather different, the fundamental forms of mediatization have a strong, global impact. In 2004, Nikolaj Arcel's Kongekabale/King's Game became a film forerunner for some of the same themes dominating Borgen. With manuscript by a former spin-doctor the film takes a close look at not just politics frontstage and backstage, the whole power game of politics, but also the relation between politicians, media and journalists. The Swedish and Scandinavian coproduced miniseries Kronprinsessan/The Crown Princess (2006) and Kungamordet/Killing of the King (2008) confirms the political film and television theme in modern Scandinavian media culture. They represent the same tendencies as Borgen in their very dramatic and emotional stories of power struggles and the public and private dimensions of politics and the entanglement of media and politics.

The rise of the theme of mediated politics in film and television drama is a clear indication of a change in the forms and representations of politics - even though this dramatic trend builds on historical traditions and dramatic prototypes dating back to the Greek tragedies and Shakespeare. But it is no wonder that documentary film and television to an even stronger degree has focused on politics and politicians in a partly new way. Danish documentary film maker Guldbrandsen has developed a revealing, close up observational style in his portrayal of modern politics, for instance in Fogh bag facaden/On the road to Europe (2003) and Prosidenten/The President (2011). Here there is a strong focus on the mediatization of politics in general and on the professional aspects of European politics. At the same time such films also show how personal and emotional dimensions enter the political game and how the political frontstage and backstage are connected and used strategically in the political process and in relation to the media. It is a documentary format that goes to the core of modern national and European politics, both on a very close up and personal micro-level and with an eye on the bigger social structures. We witness politics both as a professional job and a job in the symbolic sphere of public, strategic communication.

But perhaps the real proof of a marked shift in the way politics is represented in Scandinavian film and television is the fact that politics to a larger degree than before becomes a central part of the Scandinavian crime genre. In both the Danish series Forbrydelsen/The Killing (2007-2012) and in the Swedish-Danish coproduction Broen/The Bridge (2011-), the whole plot is related to and dependent on the interaction between political themes, the crime investigation and police work, and the private and everyday life of many of the main characters. Again the transformations of the public sphere, the new relations between frontstage and backstage, between public and private, and the rise of mediated interactions on all levels play a crucial role for the unfolding of the plot and for the main thematic strands. In The Killing both local and national political issues are woven into the different season plots, and secret links between political circles and other power structures and institutions are often central. In The Bridge, for instance, modern cyber terrorism with strong ideological and political themes are very central. In contemporary nordic noir dark forces and criminal power connections seem to undermine the image of the near perfect welfare state, and the police investigators are often haunted by personal and emotional problems.

There is no reason to assume that the Scandinavian way of dealing with the mediatization of politics is fundamentally different from US and UK examples of the same. In both political drama on film and television and in the crime traditions in all three countries, we find similar themes and ways of dealing with the public and private dilemmas of politics and the effect of media on politics. However, there is no doubt that the political culture and kind of societies created in Scandinavia, the strong dimension 
of a public welfare state, gives the modern nordic genres what Brodén (2011: 95f) has termed "the dark ambivalence of the welfare state". Where the American version of House of Cards shows the ruthless power game in a political system where the winner takes it all, or West Wing follows the inside of a presidential system, Borgen includes much broader themes, a different kind of complex political debate culture, and an often very close portrait of both existential, psychological and social aspects of a national welfare state under pressure.

Nordic noir seem to put the whole question of the survival of the Scandinavian welfare state under scrutiny. Searching for the criminals is more and more directly linked to the question of the whole state of modern Scandinavian societies, or as Nestingen (2008: 244) has said: crime is "a struggle between collective norms and individual transgression". This could indeed in general be said also about American crime and such extraordinary series like, for instance, The Wire (HBO 2002-2008, see Bondebjerg, 2012) and True Detective (HBO, 2014-). Also outside Scandinavia broader political, social and existential themes can dominate crime narratives. But the foreign reception of the nordic noir seems to indicate that the Scandinavian tradition does this in a distinct way and with a complexity that exceeds the normal standard in crime fiction. The Scandinavian legacy for this has roots back in the Swedish, critical crime tradition of Sjöwahl and Wahlö, Jan Guillou and Henning Mankell (Nestingen, 2008; Arvas and Nestingen, 2011; Brodén, 2011).

\section{The transformation of the public sphere}

In his seminal book, The Transformation of the Public Sphere (1989, org. German version 1962), Habermas described the birth of a liberal model of a public sphere. The ideal form of this public sphere according to Habermas went into decline with the gradual development of a more and more commercialized media system. Opinion building and reasoning in public was infiltrated not just by commercial interests but also by professional management, lobbying and manufacturing of ideas and politics. Habermas' term for this is "refeudalization":

Intelligent criticism of publicly discussed affairs gives way before a mood of conformity with publicly presented persons or personification; consent coincides with good will evoked by publicity (...) The suppliers display a showy pomp before customers ready to follow. Publicity imitates the kind of aura proper to the personal prestige and supernatural authority once bestowed by the kind of involved in representation. (Habermas, 1962/1989: 195)

In 2006, Habermas talked to a broad European audience of media and communication researchers, and his speech shows us a new and much more complicated understanding of politics in a mediatized society (see Fig. 1). In the published version of the article, Habermas (2006) acknowledges the tremendous increase of mediated communication in modern societies and the importance of this for public deliberation, but he also questions whether this has really served the development of a true deliberation. While on the one hand pointing towards the negative role of media barons like Murdoch and Berlusconi, he also points to "personalization, the dramatization of events, the simplification of complex matters (...) civic privatism and a mood of antipolitics" (Habermas, 2006: 422).

What this model and Habermas' whole way of thinking about the mediatization of politics in his 2006 speech acknowledges is that the public sphere has a much broader discursive register for political communication. This discursive field comprises everyday life discourses, networks and social movements, more formal

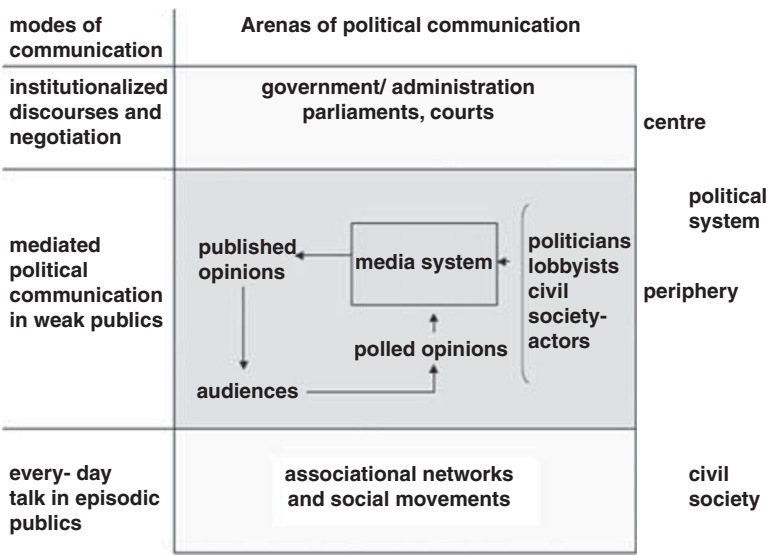

Figure 1 | Model of political communication used in Habermas' Dresden 2006 address to ICA (see Habermas, 2006: 415f). ${ }^{1}$

political institutions and networks, and a media system acting as a mediator between audiences and the politicians, through both lobbyists and civic society actors. It is a form of network society model of mediatization and politics where the former clear borders between public and private, between the political system and everyday life, and between the media and the political system are much more porous. This new and much more complex public sphere and the related forms of mediated politics is however no guarantee for the kind of ideal public deliberation that lies behind Habermas' analysis. In the article he says:

.. mediated political communication in the public sphere can facilitate deliberative legitimation processes in complex societies only if a self-regulating media system gains independence from its social environments and if anonymous audiences grant a feedback between an informed elite discourse and a responsive civil society. (Habermas, 2006: 411)

\section{Fundamental dimension of mediatization}

Habermas' criticism of certain tendencies in modern political communication is clearly valid, but the question is what the implications are of his somewhat normative position. Maybe we have to realize that the mediatization of not just politics, but culture and society as such is much more profound and that emotions, drama and the personal cannot be removed from political communication and the way media deal with politics. In Thompson's (1995) central work Media and Modernity, he offers a clear and alternative sociological approach to the historical transformation of modern societies through media and mediatization. The technological revolution of our symbolic forms of communication through media have led to a fundamental change of society and culture, a change that cannot be defined as good or bad in itself. Thompson (1995: 75) directly criticises Habermas' notion of refeudalization as "flawed" and warns against historically based theories of decay. Instead he offers an analysis of the kinds of mediated interaction that follows from modern societies with many and increasing forms of mediated communication and interaction. What we need to understand is that different types of media genres and mediated interactions have simply been integrated in our everyday life in a way completely different from before. This has fundamental implications for how we understand political communication and mediated interaction in a broader sense and also deliberation in the public sphere. 
As indicated by, for instance, Hjarvard (2013, but also Hepp, 2013), the mediatization is a change in the fundamental logics of modern societies.

By the mediatization of culture and society we understand the process whereby culture and society to an increasing degree become dependent on the media and their logic. The process is characterized by a duality, in that the media have become integrated into the operations of other social institutions and cultural spheres, while also acquiring the status of social institutions of their own right. As a consequence, social interaction-within the respective institutions, between institutions, and in society at large-increasingly take place via the media. (Hjarvard, 2013: 17)

One of the social domains of society most influenced by mediatization is politics: politics as an institution in society, politics as a kind of public discourse and politics as a central part of the day-to-day news reporting. However, politics is not just part of a news discourse, but also very much an area or a theme that dominates documentary television and film-making and the more popular forms of film and television drama. Politics is mediatized over a wide range of media and genres, it has become embedded in both journalistic public discourses and wider forms of popular discourse.

According to Thompson, the central element in the new media culture is that we are exposed to an increasing amount of symbolic and mediated communication. This feeds our imagination on possible lives and shapes our information on public and private matters: we "are confronted with countless narratives of self-formation, countless visions of the world, countless forms of information and communication, which could not all be effectively and coherently assimilated" (Thompson, 1995: 216). All of this increases not just the amount of information and communication, but also the visibility of society in front of us, creating new forms of social reflexivity. Thompson's further point is that theories of political communication and the public sphere are still too much constructed on the basis of old concepts of publics and deliberation (Thompson, 1995: 236).

Hjarvard (2013) makes a distinction between what he calls strong and direct mediatization and weak and more indirect mediatization. Although these two forms often interact, the distinction has to do with a difference between areas where media have not played a role before and areas where the mediatization has always been there, but now play an increasingly important and dominant role. An example of the latter is politics and political institutions, and one way of illustrating the mediatization of politics is to look at how it is reflected in a modern drama series like Borgen. In the opening episode of season 2, called " 89.000 children", Birgitte Nyborg as the prime minister is caught in a very difficult situation both in her family life (signing the final divorce papers) and on the political front, where a deadly incident with Danish soldiers in Afghanistan puts pressure on her war policy. Both issues involve public and private issues and questions on how to meet and address the problems in the media and in public. As in many other episodes of the series everything is mediatized: it has to do with how she looks, dresses and speaks and with what decisions she takes and how they are discursively presented to the media and to the parents of the dead soldiers. In this particular episode the dilemma also becomes a personal dilemma for the key journalist in the series, Kathrine Fønsmark (Birgitte Hjort Sørensen), caught between the tabloid logic of her boss and her personal integrity.

In the beginning of this episode, Birgitte Nyborg's spin-doctor is acting backstage to secure not just the right message in a difficult situation, but also the right personal appearance. We also see the constant exposure to the aggressive ever present press, which is part of modern politics. Krugman (2003) in NYT gave some advice on how to avoid the "style" of politics and how to focus on the content of politics: "Don't talk about clothes; actually look at the candidates proposals; beware of personal anecdotes; look at the candidates records; don't fall for political histrionics". Krugman's advice to journalists is satirical, but he knows as a commentator that the mediatization of modern politics also has to do with how to perform symbolically in the new media culture. It is impossible to reverse the effects of the increased mediatization of politics and go back to a type when the public was completely different, and where the media were much less developed and important for politics and our society and culture in general.

In 1985, Meyrowitz published an influential study, No Sense of Place. The Impact of Electronic Media on Social Behavior. He did to a large degree use Goffman's (1959/1971) theories on how we all present ourselves in everyday life, the kind of stages we play on, and the kind of roles we perform. In a chapter called "Lowering the Political Hero to our Level", Meyrowitz defines the new visibility through television by its eroding of the "barriers between the politician's traditional back and front regions" (270). Describing the performance of social roles as a kind of "multistage drama" (270) he defines the new social structure and behaviour through modern visual media as exposing the different regions, as showing us political figures moving between stages. The clear boundaries between frontstage and backstage become visible because the media gradually enter regions that used to be hidden. This in turn creates new spaces, a kind of "middle region" where public figures speak from a position mixing fronstage and backstage, private and public, and a deep backstage where public figures try to evade-often in vain:

The television camera invades politician's personal spheres like a spy in back regions. It watches them sweat, sees them grimace at their own ill phrased remarks. I coolly record them as they succumb to emotions. The camera minimizes the distance between audience and performer. (271)

\section{The new public sphere and the political persona}

According to Bennett and Entman's (2001) book Mediated Politics we see dissolution of the traditional boundaries between more clearly demarcated sectors in the public sphere. The modern public sphere is a much more loose and all comprehensive type of public sphere, in fact they see it as "any and all locations, physical or virtual, where ideas and feelings relevant to politics are transmitted or exchanged openly" (3). A public sphere in the modern, highly mediated network society is characterized by "the profusion of communication channels and permeability of boundaries separating the political from the non-political and the private sphere from the public sphere" (Ibid.).

The mediatization of modern politics also increasingly creates a permanent state of what Thompson (2000: 115) has called "the politics of trust", and a political coverage as a never-ending drama with scandal as the central plot. Thompson's (2000) book Political Scandal. Power and Visibility in the Media Age is based on the hypothesis that the traditional, ideological types of politics are declining, and that citizens are increasingly uncertain about how to relate to the more complex problems of the modern world. In this situation both the media and citizens are in need of testing the trustworthiness and credibility of politicians. The increased visibility of all stages behind politicians, the stronger role of personal credibility and communicative charisma makes scandals and credibility problems much more dominant than earlier. The media coverage and surveillance of the political process calls for 


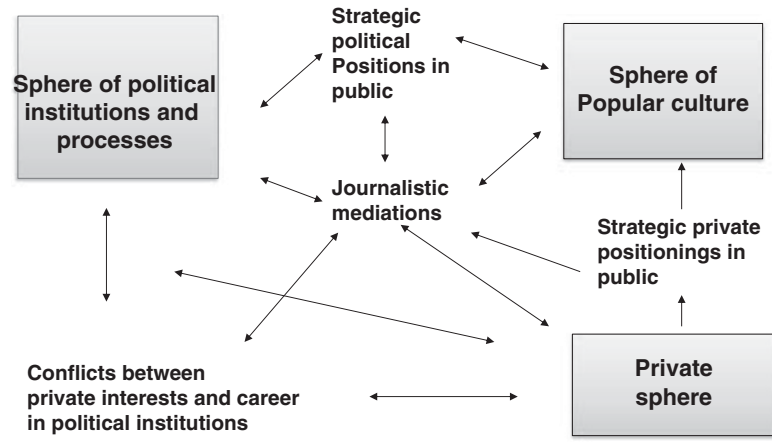

Figure 2 | The political persona and spheres of action. Inspired by Corner (2003).

stories and drama, especially on the 24-h news channels. In his book, Thompson defines three main types of political scandals: sex scandals, financial scandals and power scandals. However, all types of scandals have one thing in common:

Mediated scandals provide us with a new and unsettling view of the world which in the routine of flow of day to day life is generally hidden from view. They are windows on to a world which lies behind the carefully managed self-presentation of political leaders (...) mediated scandals (...) involve acts of transgression and the expression of moral disapproval, they also provide us with an occasion to reflect on questions a moral and practical kind (...) mediated scandals provide a rich source of conversational subject matter (...). (Thompson, 2000: 86-87)

Thompson's book on mediated scandals shows a very dark side of politics, but also of a shift in public and media attention to the personal and drama-and not always the most important drama of political contents and ideological positions. Before we rush to the conclusion that what we are witnessing is modern media causing the decline of serious politics, we must however bear in mind that politics has always been full of drama, scandals and of personal dimensions. What has changed is the intensity of mediatization and the structural complexity of the relation between media and politics.

In his article, "Mediated Persona and Political Culture", Corner (2003) describes the staging and personalization of politics and the factors influencing it (see Fig. 2). Corner wants to focus on the fact that it is impossible to neglect the political persona in politics, historically or in the present. We cannot escape the personal, emotional and dramatic elements in politics, these factors are simply imbedded in human communication and interaction. They are part of the cognitive and emotional dimensions of politics. But this does not mean that we cannot be critical about the mechanisms and structures through which the modern mediatization of politics take place. But the political persona has and will always be defined through a rather complex set of interactions between the sphere of political institutions, the sphere of popular culture and the private sphere. Modern theories of politics will have to acknowledge that mediatization has changed the fundamental logics of the game.

\section{The political documentary: politics as it unfolds}

In 2004, the Danish documentary film director, Guldbrandsen (2003), received the European Broadcasting Union (EBU) prize Golden Link Award for Fogh bag Facaden/On the Road to Europe. As reason for the prize the EBU points to the way in which the programme has managed in "bringing politicians down from their pedestal and closer to ordinary people and simultaneously do this with discretion and professionalism" (Bondebjerg, 2006: 48). The film is in the tradition of the observational cinema, and we follow the unfolding of a real story and event by observing the characters and listening to their conversations and negotiations, occasionally also with clips of interviews and comments to the camera. But there are no authoritative voice over or experts analysing what we see, and the director's voice over only gives basic information on time, place, procedures and the role of an interaction between main characters. As viewers of this film we are so to speak placed in "medias res" of a rather dramatic political event in the history of the European Union (EU): the enlargement of EU through the inclusion of the former communist countries. As viewers we are sucked into a political drama in real time, we see world politicians-and especially the Danish delegation-in both very frontstage and very backstage activities.

The film is shot with a rather small, handheld digital camera, adding to the feeling of being close to an unfolding event on all the stages where it takes place and with all sorts of dimensions, both of an ideological, political nature and of a more psychological and human dimension. In 2003, Denmark was the chair of EU and the then Danish Prime Minister, Anders Fogh Rasmussen, was in charge of the whole process leading up to the enlargement, and the final summit meeting in Copenhagen. The film opens with a triumphant frontstage celebration of the enlargement, using the hymn of the EU (theme from Beethoven's 9th Symphony) and with Anders Fogh Rasmussen, flanked by all the heads of state announcing: "Our new Europe is born". In the film we follow the Danish chairmanship, with Anders Fogh Rasmussen as the central character, from early Autumn 2002 to the final meeting in December 2003.

We actually get very close to the internal political processes and conflicts, we see some very high-ranking European politicians (French President Jacques Chirac and German Gerard Schröder, for instance) in often rather informal backstage sequences, and we also see clear examples of power games and manipulations to get things moving. We also enter a more psychological and emotional space of politics, a space where values and human dimensions and qualities play a role: either as part of a strategic national play or for the audiences and voters out there or the media, which are present throughout the programme in the form of clips from international news broadcast, or on a more personal and interpersonal level. We see strong emotional and political reactions from several political characters through the programme, not least from Anders Fogh Rasmussen and his group of people.

Guldbrandsen (2004) has said that his intention with the film was to open the EU for ordinary people and to show that political actions and human relations are intertwined. Part of the reaction to the film, both in Denmark and in the rest of the EU was in fact exactly that people were fascinated by the close up images of European politicians in action as both politicians and rather ordinary human beings. But the film also shocked some parts of Europe, for instance France, because the style of political communication in some European countries and the link between politicians and citizens is more formal and distanced. A leading article in the Danish newspaper Politiken (22 January 2004) discussed the image of politicians, with direct reference to Guldbrandsen's film and the public image of Anders Fogh Rasmussen:

Those who emphasise that leading politicians should have respect for "soft values", and that a strong drive to act is linked to empathy and compassion and emotions in general see the same competences that make him a strong leader of the 
government as something negative. Lately, it seems as though Fogh Rasmussen's advisors have realized that a softer styling is needed. (my translation)

The quote indicates a clear move in the mediatization of modern politics: politicians to a much larger degree and more instantly are not just judged by their ability to solve political problems, but very much also on style, performance and psychology. In one way this is not at all new; since the ancient Greeks, the rhetorical tradition has pointed to the interaction of logos, pathos and ethos in communication. Politics has always been a drama, where the actors are judged on all parameters. But where politicians in older times could control the public agenda and when and how they communicated to a much larger degree, the speed and complexity of modern communication has made this much more difficult. As a consequence we see new characters entering the stage: communication experts, spin doctors, and special and personal advisors.

Guldbrandsen's film on EU politics can be seen as a rare example of a film trying to go into a transnational, political space, working on the difficult relation between citizens feeling part primarily of a national public sphere, but sceptical about EU as a central political agency in modern politics Bondebjerg (2014: 174). Guldbrandsen (2011) followed up on this intention of getting close to European politics and politicians in his film The President about the process in the European Council of electing the first European president. The film follows the same strategy, but this time with European main characters much more at the centre, not least Romano Prodi, the former Italian Prime Minister. The film succeeds in getting very close to the characters as politicians and their role and attitudes towards the election, and to the politicians in a more personal way, often expressing rather sincere and open critique of how things work in this EU election process.

The President actually reuses some of the footage from The Road to Europe, but the focus this time is much more on delicate and difficult political processes in an EU trying to develop as a more efficient, political global player. But the montage of the film, even in the first $2 \mathrm{~min}$, describes the process that lead to the election of Herman van Rompuy as the first European "president" as an almost absurd drama, exposing all the problems of further integration of the EU. Guldbrandsen in his voice over talks about the event as something meant to be a proud and decisive day for Europe, the culmination of a dream of a president that could unite the EU and be the voice of Europe in global politics, just as national leaders see themselves on the international stage. Romano Prodi is quoted for saying that EU needs a strong voice and leader that can act at the global stage, the French president Chirac talks about the importance and symbolic value of a president and a voice for Europe. But as Guldbrandsen comments: EU ended up choosing an unknown Belgian, who actually did not want the job, and himself calls the whole procedure, incredible and surreal. The German politician Joschka Fischer denounce the result, by calling the whole thing "a joke" and Gerhard Schröder follows by saying that we "reached for the stars, but ended on the ground".

The opening montage very much sets the stage for a political drama, where both nations and international politicians clash and where this clash is quite openly demonstrated by the way they speak about it and interact. It is very much a story of the globalization and mediatization of politics. What is unusual in this documentary is first of all how candid and personal some of the key figures in EU are about both their visions, despair and analysis of the whole process from the rejected Nice Treaty of 2000 to the new Lisbon Treaty in 2009. To a large degree Romano Prodi becomes the voice of Europe in the film, and from his first statement in the film to the last he is the defender of a strong, integrated and federal Europe, where the splitting forces of national interests must bend for the place of Europe in a globalized world. But Prodi is not the only personality who speaks with a very personal and open voice, thus going against the public and popular image of EU as place for faceless bureaucrats. The human dimensions and the human drama behind the European political project emerge clearly here. As Prodi says towards the end: "Sometimes personal networks and relations are more important than national interests", referring concretely to Blair's warm relation to both Sarkozy and Berlusconi, even when this friendship clearly brings him on collision course with his own national parliament.

Looking at EU policy presentations in the news media, viewers or readers in their own national context often get a picture of politics as a pretty bureaucratic and not very passionate affair. In Guldbrandsen's film we get both backstage and deep backstage images of the political system, and feelings and opinions of EU key figures that actually feel something for Europe and have visions and ideas. Not just Prodi, but also the elected first president Hermann van Rompuy, Joschka Fischer, Jacques Chirac and Gerhard Schrøder all come out as more full personalities that speak their mind. This does not mean that we do not get the "dirty" backstage side of politics, which is a very clear part of the unfolding drama. Schrøder and Chirac may have the same overall vision of a new Europe, but they also fight a very old and primitive battle of national interests: the size of the agricultural support, how many votes they have in EU and so on. In Schrøder's words: “A French president is first of all French and then European, for us Germans it is somewhat different". We also see the devastating effect of the Iraq war and the division it created in the EU, and how it directly made it impossible for Tony Blair to become the first president of EU. Typical of Europe, instead they elected a completely unknown Rompuy, simply because he came from a small country and had no past, European history.

Guldbrandsen's portraits of politicians all deal with the schism between communicating political substance in ways suited to the fast and often more person and process-oriented forms of modern media. Politics has become drama and narrative. Politicians use spin doctors to formulate agendas and to influence the media stories, and media and journalists get closer to politicians as both political and private characters. The media keep chasing stories and conflicts into a deeper and deeper backstage of politics. The films of Guldbrandsen reflect a situation where the media landscape has changed dramatically. His films are part of, but also critically represent dilemmas of, modern politics and democracy in an era of almost overload of media.

\section{Narratives of power: the political drama on film and television}

Guldbrandsen's documentaries deal with the mediatization of politics seen from a classical, national and public sphere context and in a transnational European context. They deal with and try to analyse political processes connected to the triangle between politicians as public figures, the media and the institutionalized processes of politics, and the deeper backstage dimensions of the political and the personal. The mediatization of politics is, however, also clearly imbedded in modern film and television drama, as already indicated with Borgen.

Nikolaj Arcel's film, Kongekabale/King's Game (2004), is interesting because it is based on a novel by journalist, spindoctor and political commentator Nils Krause Kjær, and is very much based on true events, namely, the story of a fight for power in the Conservative party in Denmark in the 1990s. This gives the film an almost documentary like status. The fictional characters and events of the film clearly refer to actual political events and 


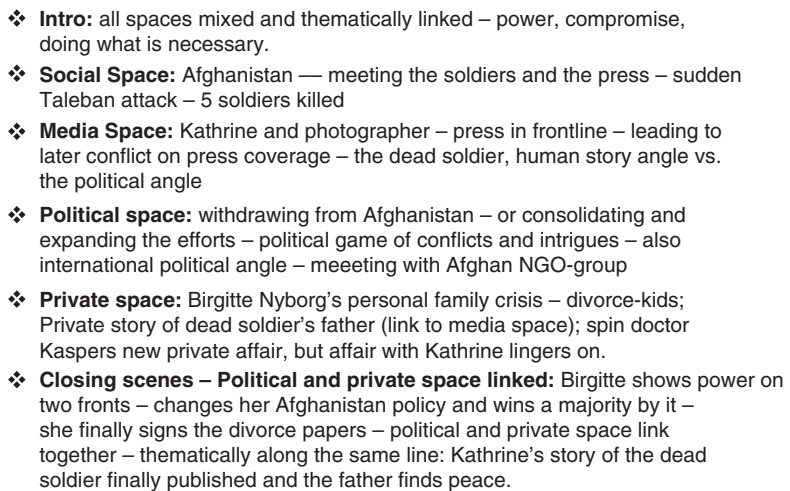

Figure 3 | Sequence structure of Borgen episode "89.000 children".

characters. The fact that the novel behind the film is written by a well-known spin doctor, who was the real spin doctor for the Conservative Party adds to the documentary reference to reality. The plot of the film follows the car accident of the leader of one the biggest Danish political parties, The Centre Party, and this creates a political situation where a heavy power struggle takes place, not just in the party but between the parties in parliament. We follow this political combat not just from the inside and through the different representatives of parties, but also through the media. The idealistic hero in the film is Ulrik Torp (played by Anders W Berthelsen) who in the beginning of the film is given the opportunity of a lifetime to become the correspondent in Parliament for the big newspaper Dagbladet. Ulrik of course gets caught up in the ruthless struggle for power headed by the party's two successors to the leadership, a narrative with some resemblance to House of Cards. Ulrik is at first clearly used by the politicians and especially the spin-doctor of the Centre Party in the internal power struggle, but eventually he uncovers a much more cynical plot that involves the country's incumbent Prime Minister. He becomes obsessed with learning the truth. But no one will listen to him, be it politicians or colleagues in the press corps, and as Election Day draws near Ulrik has to face the power elite by a counter plot that exposes the upcoming Prime Minister on live television.

So this is indeed a film about the mediatization of politics, both in the sense that the press feeds into and help create the drama and in the sense that politicians and spin-doctors cleverly play on the press to further their own case. It is therefore also about the ethical dilemma of the political press that lives day and night in parliament to a degree that they almost become part of the establishment and thus loses the role of the critical, independent press. In the intense and dramatic finale of the film, these two somewhat disillusioned, critical journalists, fighting for a more ideal role of journalism, manage in the last instance to bring down the prime minister to come. The film thus in a way shows the decline of modern journalism in the haze of spin doctors, politicians manipulating the press, the public and their opponents, but also celebrates the lone, critical journalistic hero that goes against the system. It is a sort of Danish Watergate story.

What is concentrated in this very prototypical film on the mediatization of modern politics is much more unfolded and contextualized in the drama series Borgen, a series that covers a lot of political issues of a both national and global nature during its three seasons. This drama series is "a about political power play, dealing with the personal costs and consequences of the struggles of people at the centre of the political world in Denmark and of the media covering it" (Redvall, 2013: 135). The three seasons follow a classical dramatic structure: Birgitte Nyborg's rise to power, the years in power as prime minister, the fall from power, and the fight to start a new party and regain power. The series in an almost

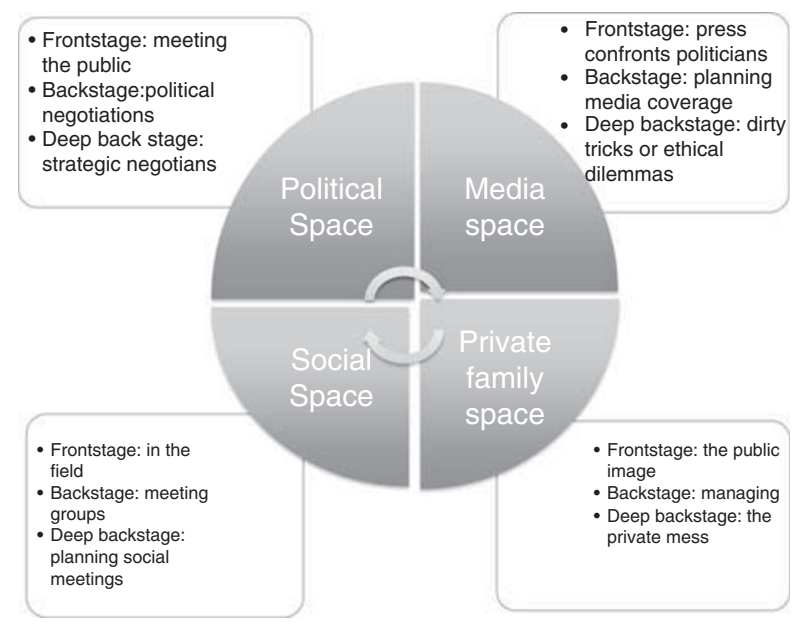

Figure 4 | The entangled spaces of Borgen.

emblematic way illustrates the transformation of politics and the shifts in the public sphere caused by mediatization and globalization. The local, national affairs of a small welfare nation state like Denmark is mixed with global issues, and public issues and debates are mirrored in the private life and the personal and emotional dimensions of modern politics and everyday life.

The creative team behind Borgen were inspired by the US series The West Wing (1999), but there was some scepticism about whether a series wholly dedicated to the politics and parliament could catch a large Danish audience. When the series was produced, the expectation of an international audience was simply not taken into consideration. But the series was developed with a focus on the idea of double storytelling that has become fundamental for Danish TV drama (see Redvall, 2013: 55ff). On the one hand, the series should have a clear dramatic conflict and narrative structure that could carry on throughout the series, on the other hand the series should raise deeper themes and structures related to politics as a democratic battle for ideas, for developing a better society. This again should be reflected in the ethical and inner psychological conflicts of both the main characters and the interaction between other characters, media and the social institutions. Birgitte Nymark's family life and her love life was part of the political plot.

It had to be a series about the soul and battle for the Scandinavian welfare state in a global and mediatized world, and the kind of life style connected with it. So the double storytelling also included a focus on psychology, everyday life, the private dimensions, the areas where the cost of politics and the strong media attention could be shown in full. Each of the political issues and themes taken up in the series are often very directly inspired by true stories. In that sense the series become a kind of reflexive revisiting of major political, ideological and social issues in Denmark since 2000-and often with major reference to European and global agendas. In season 1 we have the American prisoner transport through Greenland, in episode 6 a controversial visit from a former Soviet republic. In season 2 we have the episode "89.000 children" related to Denmark's involvement in Afghanistan and an episode (no. 2) with strong focus on EU. In the following I will analyse the episode " 89.000 Children" more in depth to demonstrate how the series manage to bring together very different themes and narrative threads (Fig. 3).

We can describe the narrative and thematic structure of Borgen very much in direct relation to the models presented for the modern, mediatized public sphere and the intensified relations between frontstage, backstage and deep backstage in four main spaces (see Fig. 4): political space: politics/parliament; the media 
space; the private family space; and the social space (nationally/ internationally).

The intro clearly sets the theme and connects the different spaces in the series, and throughout all the episodes of the series there is an intense, dramatic and narrative drive in the way in which we move between these spaces. It is not only the case that the series move between these four main spaces. The whole dynamic and construction of the story is based on a premise that modern politics is defined by how these spaces are linked and influence each other. Underneath the four main spaces we find the three different stages the characters are playing on. The frontstage is of course the stage where the main characters face the public, either directly or through the media; the backstage is where everything that is to become part of a public performance is prepared, negotiated and discussed, this is also where political or private battles are fought. Deep backstage then is actually a place which we should not be allowed into, because this is where psychological breakdowns happen and are repaired. This is where all the moral and ethical questions haunt us, where we try to face not even our actions in public space but our actions dealing with the planning of our acts in the public space. This is the area of secret meetings in the dark corners of parliament or in private, it is those intimate, sexual moments that should not have happened, relations between people that are unethical.

They are all there in every episode and season of Borgen, and in this particular episode the connections are very strong. With reference to the sequence overview in Fig. 3, we can see that we start in global politics, a confrontation on the highest political levels, but the situation with dead Danish soldiers soon become national politics and a question of handling the media, of not loosing face, particular for a female prime minister. But this public and mediatized political issue is also followed to the deepest, personal and emotional levels. This happens when the story of the father of one of the dead soldiers is unfolded in the media and fuelled into the political context, and when this personal dimension becomes of human and ethical concern for both the journalist Kathrine Fønsmark and Birgitte Nyborg. All of this is finally taken to an even deeper level, as Birgitte Nyborgs political dilemmas are confronted with the needs of the 89.000 Afghan children dependent on help to have a future, and her own private mess and the needs of her own children. Everything is thematically and narratively linked in this episode, which fully explores the complexity of modern, mediated politics and globalized societies.

In all four spaces we then find these different stages represented, and they tell us about a public sphere, in which the mediatization of politics has moved the borders between public and private. Borgen shows us power games and strategic games in which the media are both deeply involved and which the media also try to expose. But the image of politics is also an image of things in modern societies that go beyond politics and the ways in which professional media act, whether it is the tabloid press and media or more serious, critical media. The development of new social media and digital platforms have changed the ways in which, and the intensity with which, ordinary citizens interact and expose their life in public. The erosion of the traditional boundaries between public and private, between front- and backstage is not just a political phenomenon.

\section{Nordic noir and politics}

As already indicated, the nordic crime novel dating back to the 1970s (Nestingen, 2008; Arvas and Nestingen, 2011; Brodén, 2011; Agger, 2012) has always been about much more than solving individual crimes. The crime genre, now often known as the "nordic noir" tradition, has, in the word of Forshaw (2012: 2), systematically investigated "the cracks that have appeared in the social democratic ideal". Just as Sjöwahl and Wahlö created narratives that were critical towards the vey institutions of the nordic welfare society that were supposed to stand guard for democracy and equality, so did Stieg Larsson in his novels, very fast adapted for the screen, cast a deep, critical light on both the history and contemporary forms of Scandinavia. If for some reason, real or not, the Scandinavian welfare society stand out internationally as an ideal society without strong tensions and conflicts, the international interest in nordic noir could have something to do with the fact that the darker backside of this myth is exposed mixing fascination and surprise. There is in fact after all something rotten in Scandinavia that brings the story in line with general trends in other societies (Agger, 2012: 41).

Crime on film and television often involve dimensions having to do with those in power, be it big companies, the financial capital or the whole political power structure. Corruption and crime range high and low in all societies. The concept nordic noir was originally used, it seems, by the British distributor of Scandinavian crime series, Arrow Film, in the wake of the success of series like the Swedish Wallander, the Danish The Killing and the Danish-Swedish coproduction The Bridge. The term in itself aesthetically refers to the noir style of often darkness, bleak urban landscapes, and very gloomy and tragic themes and narratives, but clearly the noir term also have social connotations. Since Scandinavia is often seen as the place of light and of wellfunctioning welfare states, the darkness addressed in these crime series also has to do with a threatening social and political decay.

Nordic noir-following also the principle of double storytellingis not just about crime. It is about crime in the contexts of society as such and its institutions, among them the political and capitalist power structure. This is very clear in the Danish series The Killing, where the development through the three seasons furthermore expands the connections between the basic crime plot and more and more entangled dimensions of the local, the national and the global. In the first season of The Killing, the central crime plot with the murdered girl is a very local matter, and the murderer is very close to the family. But the crime plot is also for a long time deeply entangled with political battles and intrigues at Copenhagen City Hall. The main political character, Troels Hartman, played by Lars Mikkelsen, is exposed both frontstage, backstage and deep backstage as a public figure in the media and as a private person. For a long time we are brought to believe that there is a crucial connection between the crime story and the political story. The fact that politics and politicians are so centrally involved in a popular crime plot from beginning to end of the first season indicates how deeply politics has been mediatized and part of the narratives that popular culture is made of.

The tendency in season 1 to combine a political plot with the crime plot continues with even stronger force in seasons 2 and 3 . In season 2, the murders are not just tied directly to national interests and the politics of war, but also to national myths going all the way back to WW2 and the Danish resistance. The political elite, the military elite and even the police are deeply involved. The crime story thus becomes a story with social critique of the dark sides of the Danish welfare state and society, and the murderer is directly linked to the police itself and to the military. The same tendency can be seen in season 3, where the background for the crime plot is the financial crisis and the foul play by big companies, the financial capital and parts of the political system and the government. Sarah Lund's desperate and shocking last action as police officer in the series, taking the case in her own hands to secure social justice, indicates the radical nature of the social critique in this crime series. In this last and perhaps most dramatic and dark season, global powers are clearly present, and we are beyond the traditional boundaries of the national welfare state. 
It is no surprise then that the deep social tendency in Danish TV crime drama continue when Swedish and Danish creative powers are combined in The Bridge. In the first series of The Bridge, the split torso found on the bridge between Denmark and Sweden is partly a female politician and a prostitute. The corpse and the way it is placed is a symbolic protest from the killer, who turns out to be a terrorist with very radical social and political agendas. The very process of solving the case is directly linked to several, contemporary political agendas, politics is so to speak at the centre of crime and police work. Although in a very drastic and brutal way, the series is not just about the police and crime, but also about issues that threaten the way we live and run our society. As in Borgen, the private lives of the main characters, the fact that their life in many ways is a mess and, in crisis, that they suffer also through their families becomes part of the crime series. Also here the private and the public are deeply connected in a media saturated society where also the criminals know how to use the media for their own agenda.

\section{Concluding remarks}

In the digital media culture, search machines can access and digest information in a very short span of time. Everything seems very much out into the open, and both the citizens in general and politicians and politics are online around the clock on social media. We seem to live in what Keane (2013: 2) has called the "age of communicative abundance" and which he illustrates with a dense graphic illustration of global internet traffic. Keane treats this development with a sort of sceptic pragmatism. The new media culture can be seen as an empowering of the citizen, as a democratization of information. On the other hand, the new information society is also dominated by centralized power. The erosion of traditional distinctions between private and public lead to relentless "muckracking" of public figures (40f), the rise of what he calls "unelected representatives" (55f) and the increased importance of transnational or cross-border publics (64f). As always, when social and technological transformations happen, we see new trends and tendencies in public and private communication, but also a continuation of established power structures. "Online technologies do not in themselves point to a new space for democracy (...) it is still very much the same old fight with old and new players positioning themselves in relation to a new media culture" (Bondebjerg, 2010: 114).

The mediatization of almost all aspects of modern life is a development we cannot reverse. As already Goffman pointed out in 1959, humans have always played on different stages, regardless of the presence of media. It is part of the way we socially interact and communicate, it is both in our biology and our social genes. The omnipresence of all types of media clearly enhance our ability to follow politics both front and backstage, and a series like Borgen in a very convincing and realistic way tells us about the professional and personal games and costs of modern politics. But just as the media have always come in many forms, from tabloid media speaking into forms of popular culture to high-quality media for elites, politics expresses itself in different discourses and practices. We may well side with Goodman in her 1998 San Francisco Chronicle comment (5 November): "Every Generation gets the Thomas Jefferson it deserves (..) The Jefferson today is one of sex, scandal and hypocrisy", especially because her statement refers to a very tabloid affair in American politics-the Lewinsky affair. But we must not generalize from spectacular cases and politics is certainly more than scandals, even today.

It would be overly pessimistic to just talk about the total decline of serious politics and arguments, and it would be too easy to just blame the media. The media have certainly influenced the way contemporary politics is communicated and understood, and the rise of audio-visual media have made it impossible to escape the personification of politics. On the other hand, modern media have also greatly increased the scope and knowledge of politics and in many ways moved politics closer to everyday life and the ordinary citizen. Politics has become a strong part of many genres and narratives on film, television, print media and on the internet. As studies in the national and international reception of Borgen and The Killing (Bondebjerg and Redvall, 2015) have shown, we actually see an increase in public interest and debate about politics and social themes in connection with such series. The awareness of national differences is also clearly highlighted. The cultural and symbolic power and importance of politics for the future of our life and our society have moved deeper into popular culture-for better and for worse.

In Schudson's (1998) book The Good Citizen, where he maps the historic layers of civic types in American history, he also in the last chapter addresses the question of decline and the role of the media for democracy and political life. He is obviously not very convinced by laments about decline and he opens his last chapter with the words: "Citizenship in the US has not disappeared. It has not even declined. It has, inevitably, changed" (Schudson, 1998: 294). He goes through six different ways of measuring the quality of public life, one of them being the quality of public discourse. Although not uncritical of the media development, he nevertheless points to overwhelmingly positive aspects of what he calls "the greater openness and rawness of public talk" and the greater access to news and media in general (Schudson, 1998: 304f).

\section{Note}

1 Habermas' speech was published the same year in Communication Theory Vol. 16, but the model was not reproduced here, although a type of model is clearly developed in the article text.

\section{References}

Agger G (2012) Nordic noir on television: The Killing I-III. In Cinéma \& Cie International Film Studies Journal; XII (19): 39-50.

Arvas P and Nestingen A (eds) (2011) Scandinavian Crime Fiction. University of Wales Press: Cardiff, UK.

Bennett L W and Entman R M (eds) (2001) Mediated Politics: Communication in the Future Democracy. Cambridge University Press: Cambridge.

Bondebjerg I (2006) Politics back stage. Television documentaries, politics and politicians. Politik; 9 (2): 45-54.

Bondebjerg I (2010) A new space for democracy+ online media, factual genres and the transformation of traditional media. In: Gripsrud J (ed). Relocating Television. Television in the Digital Context. Routledge: London, pp 113-125.

Bondebjerg I (2012) From Dynasty to the Wire. American Tv series and the sociology of creative media industries. In: Hovden J F and Knapskog K (eds). Hunting High and Low. Scandinavian Academic Press: Oslo, Norway, pp 266-287.

Bondebjerg I (2014) Engaging with Reality: Documentary and Globalization. Intellect Books.

Bondebjerg I and Redvall E N (2015) Breaking borders-The international success of Danish television drama. In: Bondebjerg I, Redvall E N and Higson A (eds) European Film and Television: Cultural Policy and Everyday Life. Palgrave Macmillan: Basingstoke, UK.

Brodén D (2011) The dark ambivalence of the welfare state: Investigating the transformations of the Swedish crime film. Northern Lights: Film and Media Studies Yearbook; 9 (1): 95-109.

Corner J (2003) Mediated persona and political culture. In: Corner J and Pels D (eds). Media and the Restyling of Politics. Sage: London, 67-85.

Forshaw B (2012) Death in a Cold Climate: A Guide to Scandinavian Crime Fiction. Palgrave Macmillan: Basingstoke, UK.

Goffman E (1959/1971) The Presentation of Self in Everyday Life. Penquin Books: London.

Goodman E (1998) Never mind if Tom loved Sally. San Francisco Chronicle, 5 November, p A29.

Guldbrandsen C (2004) Interview. Kommunikationsforum, http://www.kommuni kationsforum.dk, 13 February.

Habermas J (1962/1989) The Structural Transformation of the Public Sphere. Polity Press: Cambridge. 
Habermas J (2006) Political communication in media society: Does democracy still enjoy an epistemic dimension? The impact of normative theory on empirical research. Communication Theory; 16 (2006): 411-426.

Hjarvard S (2013) The Mediatization of Culture and Society. Routledge: London.

Keane J (2013) Democracy and Media Decadence. Cambridge University Press: Cambridge, UK.

Krugman P (2003) New Year's resolutions. New York Times, 26 December.

Lakoff G (2008) The Political Mind. Tantor Media: New York.

Meyrowitz J (1985) No Sense of Place: The Impact of Eelectronic Media on Social Behavior. Oxford University Press: London.

Nestingen A (2008) Crime and Fantasy in Scandinavia: Fiction, Film and Social Change. University of Washington Press: Seattle, Washington DC.

Politiken G (2004) Bag facaden (Behind the facade). Leading article, January 22.

Redvall E N (2013) Writing and Producing Television Drama in Denmark: From the Kingdom to the Killing. Palgrave Macmillan: Basingstoke, UK.

Schudson M (1998) The Good Citizen: A History of American Civil Life. The Free Press: New York.

Thompson J B (1995) Media and Modernity: A Social Theory of the Media. Polity: London.

Thompson J B (2000) Political Scandal: Power and Visibility in the Media Age. Polity Press: Cambridge.

\section{Acknowledgements}

This article is based on a lecture given at Princeton University, Centre for Modern European Politics in April 2014. I thank Jan-Werner Müller for inviting me and for comments on both the lecture and this article.

\section{Additional Information}

Competing interests: The author declares no competing financial interests.

Reprints and permission information is available at http://www.palgrave-journals.com/ pal/authors/rights_and_permissions.html

How to cite this article: Bondebjerg Ib (2015) The mediatization of politics in contemporary Scandinavian film and television. Palgrave Communications 1:15003 doi: 10.1057/palcomms.2015.3.

\section{(ㄷ) (1)}

This work is licensed under a Creative Commons Attribution 3.0 International License. The images or other third party material in this article are included in the article's Creative Commons license, unless indicated otherwise in the credit line; if the material is not included under the Creative Commons license, users will need to obtain permission from the license holder to reproduce the material. To view a copy of this license, visit http://creativecommons.org/licenses/by/3.0/ 